\title{
Svanen i mindre samhällen \\ - hur kan man stödja utvecklingen?
}

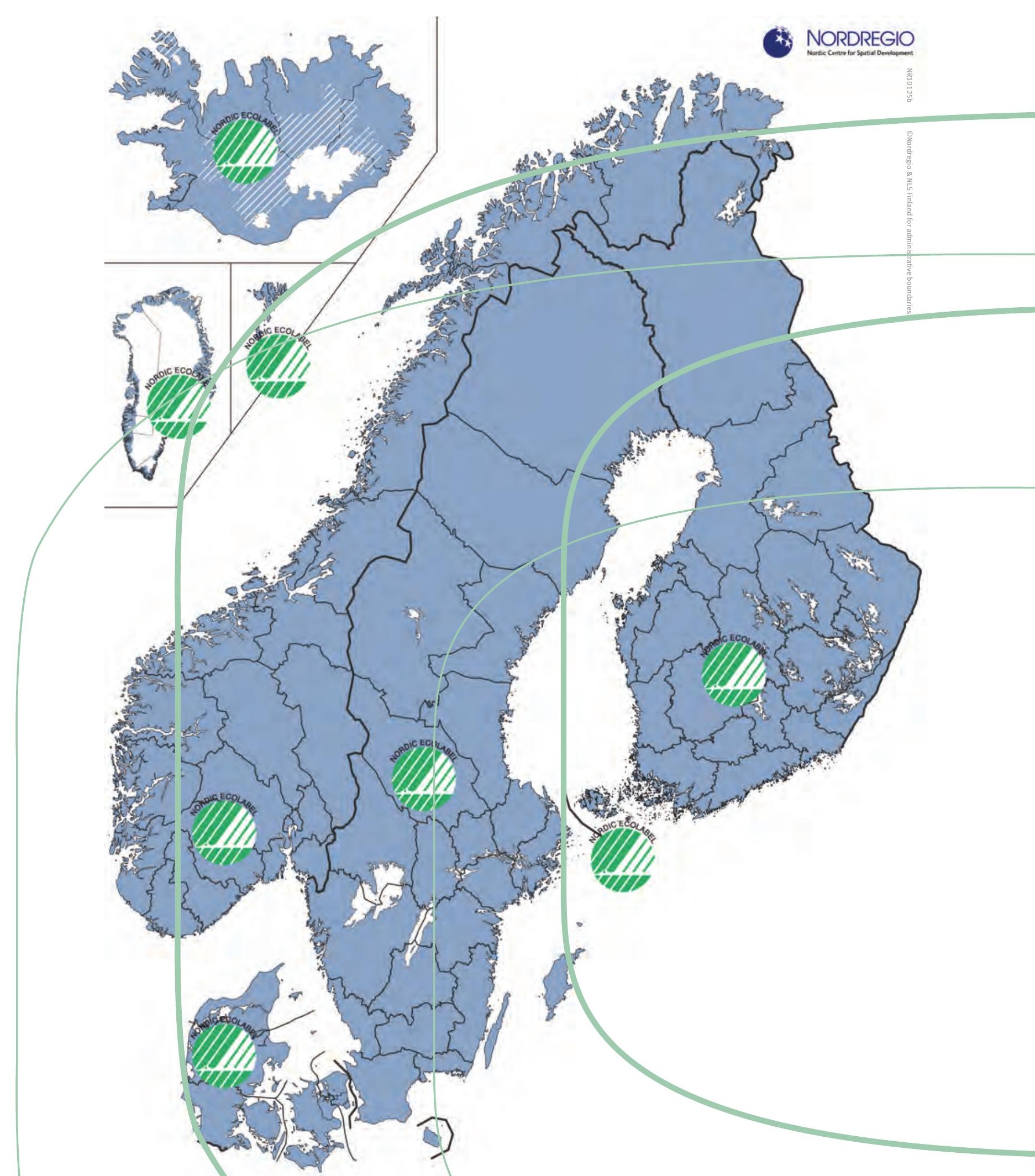



4 norden 



\section{Svanen i mindre samhällen - hur kan man stödja utvecklingen?}

Stefán Gíslason

TemaNord 2013:580 
Svanen i mindre samhällen - hur kan man stödja utvecklingen?

Stefán Gíslason

ISBN 978-92-893-2657-5

http://dx.doi.org/10.6027/TN2013-580

TemaNord 2013:580

(C) Nordiska ministerrådet 2013

Layout: Hanne Lebech

Omslagsfoto: Calle Karlsson/Kavat

Denna rapport är utgiven med finansiellt stöd från Nordiska ministerrådet. Innehållet i rapporten avspeglar inte nödvändigtvis Nordiska ministerrådets synpunkter, åsikter eller rekommendationer.

www.norden.org/sv/publikationer

\section{Det nordiska samarbetet}

Det nordiska samarbetet är ett av världens mest omfattande regionala samarbeten. Det omfattar Danmark, Finland, Island, Norge och Sverige samt Färöarna, Grönland och Åland.

Det nordiska samarbetet är politiskt, ekonomiskt och kulturellt förankrat och är en viktig partner europeiskt och internationellt samarbete. Den nordiska gemenskapen arbetar för ett starkt Norden i ett starkt Europa.

Det nordiska samarbetet ska stärka nordiska och regionala intressen och värderingar i en global omvärld. Gemensamma värderingar länderna emellan bidrar till att stärka Nordens ställning som en av världens mest innovativa och konkurrenskraftiga regioner.

\section{Nordiska ministerrådet}

Ved Stranden 18

DK-1061 København K

Telefon (+45) 33960200

\section{www.norden.org}




\section{Innehållsförteckning}

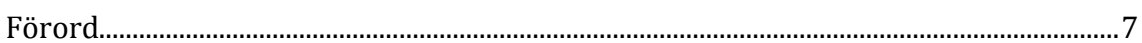

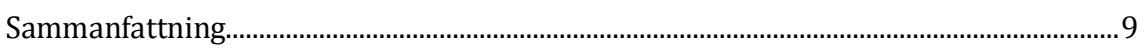

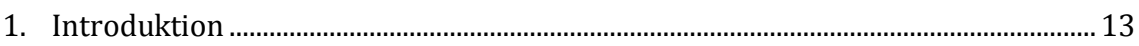

1.1 Bakgrund ...................................................................................................... 13

1.2 Syfte och mål ........................................................................................................ 14

1.3 Omfattning och avgränsning …….............................................................. 15

1.4 Metoder.............................................................................................................. 16

1.5 Rapportens struktur.......................................................................................... 16

2. Avgiftsstruktur............................................................................................................ 17

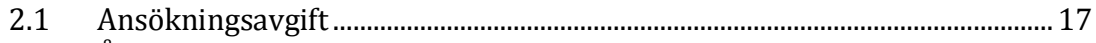

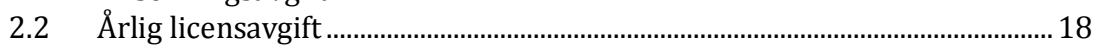

2.3 Speciella bestämmelser för småföretag ........................................................... 18

2.4 Exempel på ekologisk certifiering .................................................................... 19

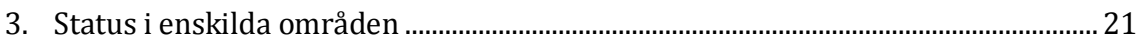

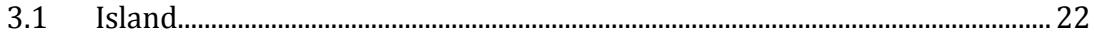

3.2 Färöarna............................................................................................................ 24

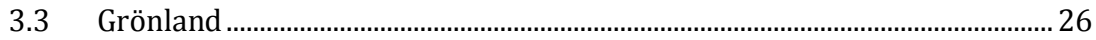

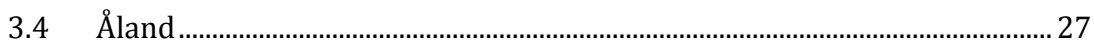

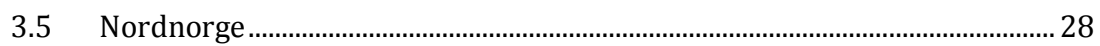

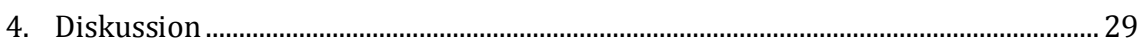

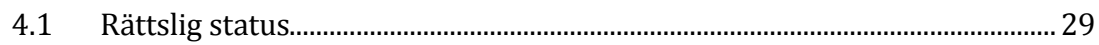

4.2 Efterfrågan .................................................................................................. 29

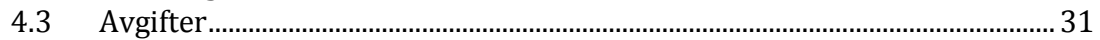

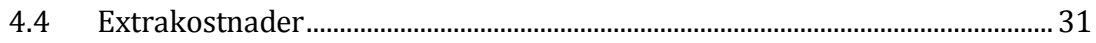

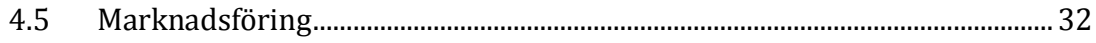

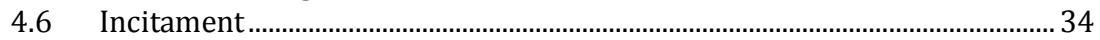

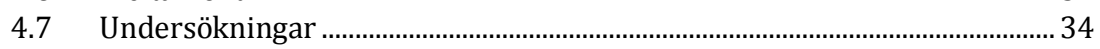

4.8 Språk

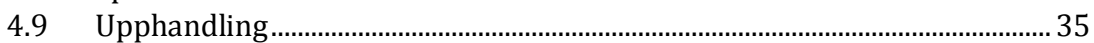

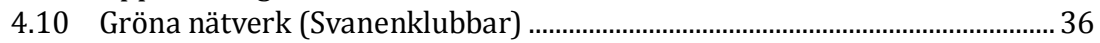

4.11 Konkurrens med övriga märken ........................................................................ 37

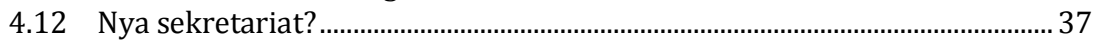

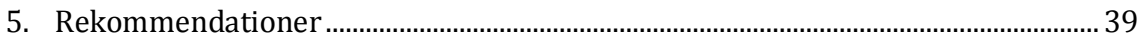

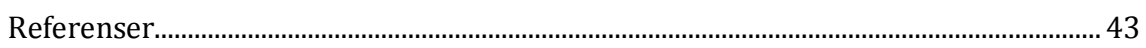

Litteratur och webbsidor ........................................................................................... 43

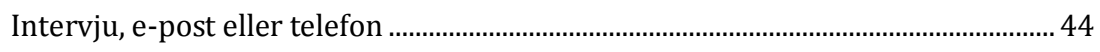

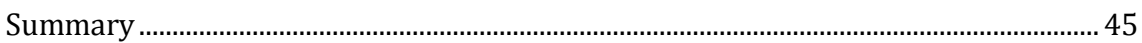





\section{Förord}

Det nordiska miljömärket Svanen bedöms vara ett av de bästa exemplen på framgångsrikt arbete med miljömärkning i hela världen. Svanen har en stark ställning i Norge, Sverige, Finland, Danmark och Island, men framgången har inte varit lika stor i de självstyrda områdena. På Grönland har hittills ingen Svanenlicens utdelats, på Färöarna finns det endast två Svanenmärkta företag och på Åland fyra.

Hösten 2012 publicerade Nordiska ministerrådet ett häfte med 18 goda exempel ("succéhistorier") på miljömärkning av varor eller tjänster från små företag i mindre samhällen i Norden. Dessa exempel visar att miljömärkning inte bara är möjlig utan också lönsam, inte bara i storstäderna utan också i mindre samhällen. "Succéhistorierna" kommer att publiceras på färöiska, isländska, norska och finska hösten 2013.

Denna rapport bygger vidare på "succéhistorierna" och innebär en närmare och mer detaljerad undersökning av vilka styrmedel som skulle kunna användas för att göra Svanen mer tillgänglig/aktuell för producenter av varor och tjänster i mindre samhällen i Norden. Stefán Gíslason i Environice på Island har skrivit rapporten på uppdrag av Nordiska ministerrådets Småsamfundsgrupp, som är en undergrupp till ministerrådets arbetsgrupp för hållbar produktion och konsumtion (HKPgruppen). Det bör framhävas att rapportens rekommendationer är författarens och återspeglar inte nödvändigtvis Småsamfundsgruppens synpunkter. Trots detta skulle de kunna vara ett viktigt underlag för gruppens framtida arbete med att stärka Svanens ställning i mindre samhällen i Norden. 
Ett flertal personer har hjälpt till med denna sammanställning. Samtliga förtjänar ett stort tack. Ett särskilt varmt tack går till Småsamfundsgruppens medlemmar och till medarbetarna i de nationella miljömärkningssekretariaten som bidragit till sammanställningen med sina kunskaper och erfarenheter.

Oktober 2013
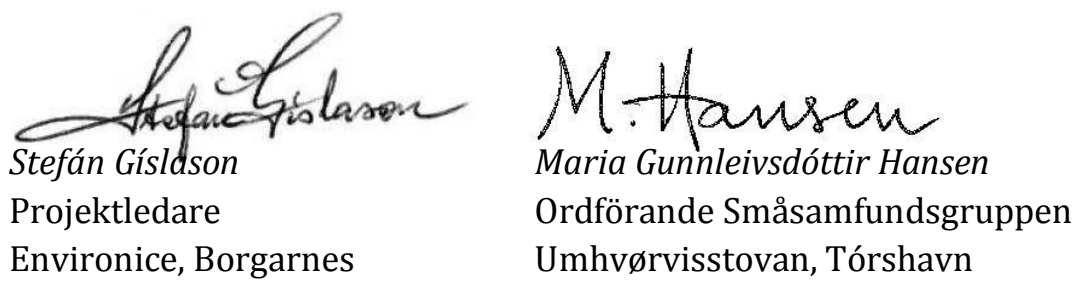


\section{Sammanfattning}

Det nordiska miljömärket Svanen bedöms vara ett av de bästa exemplen på framgångsrikt arbete med miljömärkning i hela världen. Svanen har under en längre tid haft en mycket stark ställning i Norge, Sverige, Finland och Danmark. På Island har det också skett en snabb utveckling under de senaste fyra åren, vilket avspeglas i att antalet Svanenlicenser mer än femdubblats på 4 år. Däremot har Svanen inte haft lika stora framgångar i övriga mindre samhällen i Norden. På Grönland har hittills ingen Svanenlicens utdelats, på Färöarna finns det endast två Svanenmärkta företag och på Åland fyra.

Hösten 2012 publicerade Nordiska ministerrådet ett häfte med 18 goda exempel ("succéhistorier") från små företag som verkar i mindre samhällen i Norden och som fătt sina varor eller tjänster miljömärkta med Svanen eller EU Ecolabel. Dessa exempel visar att miljömärkning inte bara är möjlig utan också lönsam, inte bara i storstäderna utan också i mindre samhällen. Innevarande projekt bygger på dessa "succéhistorier" och innebär en närmare och mer detaljerad undersökning av vilka styrmedel som skulle kunna användas för att göra Svanen mer tillgänglig/aktuell för producenter av varor och tjänster i mindre samhällen i Norden.

I nuläget finns det kriterier för Svanenmärkning av 61 olika produktgrupper. Endast ett begränsat antal av dessa är aktuella i mindre samhällen i Norden, eftersom det bortsett från fiskeindustrin finns förhållandevis få tillverkningsindustrier i de berörda områdena. Däremot finns det många olika serviceföretag, inte minst inom turistbranschen, där miljömärkning borde vara högst aktuell, särskilt i ljuset av hur beroende turistbranschen är av den oförstörda naturen.

Enligt en ungefärlig uppskattning av antalet företag inom aktuella produktgrupper och andelen företag som fătt Svanen för sina produkter eller tjänster har endast 31 företag av ca 1700 på Island, Färöarna, Åland och Grönland fått Svanen för sina produkter eller tjänster. Det verkar alltså finnas en stor potential för Svanenmärkning i de berörda områdena, särskilt inom tjänstesektorerna, och då speciellt hotell, restauranger och dagligvarubutiker. Tryckerier, städtjänster och tvätterier har också en förhållandevis stor potential. 
Två huvudfaktorer har nämnts som förklaring till Svanens framgång på Island under de senaste 4 åren: en målmedveten politisk inriktning samt en fungerande policy för grön offentlig upphandling. Av denna erfarenhet borde man kunna dra lärdomar som kan användas i övriga områden. Det bör dock beaktas i detta sammanhang att som ett självständigt medlemsland i Nordiska ministerrådet skiljer sig Island från Färöarna, Grönland och Åland när det gäller miljömärkning. På Island har Svanen en formell och rättslig status som officiellt miljömärke och där har Svanen sitt nationella miljömärkningssekretariat. Företag på Färöarna, Grönland och Åland måste däremot lita på service från de nationella sekretariaten i något av de 5 medlemsländerna i Nordiska ministerrådet.

Enligt information från nationella miljömyndigheter på Färöarna, Grönland och Åland samt från de nationella miljömärkningssekretariaten har man inte noterat någon stor efterfrågan på miljömärkning från företag i de självstyrda områdena. Inga större slutsatser kan emellertid dras av detta förrän frågan utforskats mer i detalj. En låg efterfrågan kan t.o.m. bero på att företagen inte upplever miljömärkningssekretariatens service som tillgänglig p.g.a. geografiskt eller språkligt avstånd, samt på att det formellt sett inte finns någon mottagare inom det offentliga för en sådan efterfrågan.

Utifrån den information som framkommer i denna rapport rekommenderas inte att nya miljömärkningssekretariat etableras i de självstyrda områdena. Däremot borde nationella miljömyndigheter ta initiativ till informationskampanjer om miljö och miljömärkning i de självstyrda områdena i samarbete med och med professionellt stöd från miljömärkningssekretariateten i Danmark, Sverige, Finland, Norge eller Island. En nordisk "roadshow" rekommenderas som ett första steg i detta, t.ex. i form av en temadag i varje område, där man informerar om Svanen och miljömärkning i övrigt och samtidigt söker skapa en översikt över det aktuella intresset i det berörda området/landet. Nordiska medel borde gärna användas för förberedelse och samordning av detta samt för ersättning för resekostnader, medan det lokala genomförandet kan finansieras med nationella medel. Om intresse finns kunde ett nästa steg vara mer sektorspecifikt och/eller riktat mot specifika kundgrupper, t.ex. småbarnsföräldrar.

Behovet av informationskampanjer varierar mellan olika länder/områden. På Åland borde fokus sättas på företag som primär målgrupp. På Färöarna borde fokus sättas på företag samt på allmänheten. På Grönland borde allmänheten vara den primära målgruppen.

Främjandet av grön offentlig upphandling är en annan åtgärd som rekommenderas för att stödja utvecklingen av Svanen i mindre sam- 
hällen i Norden. Utbildning av inköpsansvariga för t.ex. tvätteri-, rengörings- och tryckeritjänster rekommenderas som ett första steg i detta, medan inarbetandet av gröna kriterier i nationella riktlinjer för inköp kan sättas i gång när de grundläggande inköpsreglerna fastställts.

Bland andra rekommendationer i rapporten finns inrättandet av "Svanenklubbar", översättning av material, utbildning av Svanenkonsulter, undersökningar av kunskap om Svanen och befintliga Svanenmärkta produkter, samt att miljömyndigheterna på Färöarna utnämner en av sina medarbetare till kontaktperson med rollen att hjälpa till med kontakter mellan färöiska företag och miljömärkningssekretariatet i Köpenhamn eller ev. Reykjavik. 



\section{Introduktion}

Hösten 2012 publicerade Nordiska ministerrådet ett häfte med 18 goda exempel ("succéhistorier") från små företag som verkar i mindre samhällen i Norden och som fătt sina varor eller tjänster miljömärkta med Svanen eller EU Ecolabel. ${ }^{1}$ Dessa exempel visar att miljömärkning inte bara är möjlig utan också lönsam, inte bara i storstäderna utan också i mindre samhällen. Stefán Gíslason i Environice på Island gjorde sammanställningen på uppdrag av Nordiska ministerrådets Småsamfundsgrupp, som är en undergrupp till ministerrådets arbetsgrupp för hållbar produktion och konsumtion (HKP-gruppen).

Detta projekt bygger på dessa "succéhistorier" och innebär en närmare och mer detaljerad undersökning av vilka styrmedel som skulle kunna användas för att göra Svanen mer tillgänglig/aktuell för producenter av varor och tjänster i mindre samhällen i Norden.

\subsection{Bakgrund}

I dagsläget finns det endast två producenter på Färöarna som fått sina produkter och/eller tjänster Svanenmärkta. Färöarna har inte något eget miljömärkningssekretariat, utan sekretariatet i Danmark har skött märkningen och den service som behövs. På Åland finns det 4 företag som fått Svanen på sina tjänster med stöd från sekretariaten i Helsingfors eller i Stockholm. På Grönland finns det inga. För bara 3 år sedan var situationen på Island inte mycket annorlunda. I slutet av år 2008 fanns det t.ex. endast 4 Svanenlicenser på Island. Detta antal ökade till 23 till hösten 2012, d.v.s. mer än femdubblades på 4 år. Detta sägs vara en konsekvens av målinriktat arbete inom den isländska miljömärkningsnämnden och Umhverfisstofnun, som fungerar som det isländska Svanensekretariatet. Samtidigt har ett starkt tryck skapats genom offentlig grön upphandling med krav på miljöanpassade tjänster, särskilt

${ }^{1}$ Nordiska ministerrådet (2012): Svanen och EU Ecolabel. Succéhistorier i nordiska småsamfund. Nordiska ministerrådet, Köpenhamn. http://www.norden.org/sv/publikationer/publikationer/2012-553 
när det gäller rengörings- och tryckeritjänster. Av denna erfarenhet borde man kunna dra lärdomar som kan användas i övriga områden.

Färöarna, Grönland och Åland har inte samma förutsättningar som Island när det gäller miljömärkning, delvis p.g.a. en olik politisk struktur och delvis p.g.a. ett lägre invånarantal samt en mindre inhemsk marknad. Det har också påpekats att bortsett från fiskeindustrin på Färöarna och Grönland finns det förhållandevis få tillverkningsindustrier i dessa länder, samtidigt som det inte finns konkurrens mellan dessa. Däremot finns det många olika serviceföretag, inte minst inom turistbranschen, där miljömärkning borde vara högst aktuell, särskilt i ljuset av hur beroende turistbranschen är av den oförstörda naturen.

En annan sak som skiljer Island från Färöarna, Grönland och Åland när det gäller miljömärkning är att som ett självständigt medlemsland i Nordiska ministerrådet har Island givit Svanen formell och rättslig status som ett officiellt miljömärke. Dessutom har Svanen sitt nationella miljömärkningssekretariat på Island, medan företag på Färöarna, Grönland och Åland måste lita på service från de nationella sekretariaten från Danmark resp. Finland, samt för Ålands del i vissa fall också Sverige.

Det faktum att Svanen inte har formell och rättslig status som ett officiellt miljömärke på Färöarna, Grönland och Åland behöver inte vara ett hinder för att Svanen ska få fotfäste i dessa områden. Det skulle också vara ganska dyrt att kontrollera t.ex. en rengöringsfirma i Tórshavn eller ett hotell i Nuuk om detta måste göras från Köpenhamn eller möjligen från Reykjavik. Ett kontrollbesök behövs innan ett företag făr licens, vilket innebär stora kostnader för miljömärkningssekretariaten om ansökningar börjar komma in från de självstyrda områdena. Samma sak gäller i princip också för Åland, förutom att resan dit inte blir lika dyr och tidskrävande p.g.a. av ett kortare avstånd och lägre resekostnader från Helsingfors eller Stockholm.

Det bör i detta sammanhang framhävas att företag i mindre samhällen i Norden inte alla står inför samma typ av utmaningar. Detta varierar mellan olika delar av Norden liksom mellan mindre och större företag.

\subsection{Syfte och mål}

Detta projekt syftar till att identifiera hinder som motverkar en vidare utveckling av miljömärkningen i mindre samhällen, och således att skapa ett pålitligt underlag för beslut om att stärka Svanens ställning, framför allt på Färöarna och Grönland men eventuellt även på Åland. För 
detta behövs en närmare beskrivning av Svanens position i mindre samhällen i Norden, inkl. följande punkter:

- Översikt över nuvarande organisation och finansiering av Svanenarbetet i enskilda mindre samhällen i Norden.

- Utredning av orsaker till att få företag tillverkar Svanen-märkta produkter och tjänster.

- Identifiering av befintliga hinder.

Baserat på detta tar projektet fram förslag/rekommendationer på åtgärder/initiativ för att öka antalet Svanenmärkta företag (varor/tjänster) i mindre samhällen i Norden, samt en beskrivning av hur detta arbete bäst kan organiseras och finansieras.

\subsection{Omfattning och avgränsning}

För närvarande är Island, Färöarna, Åland och Nordnorge aktiva i Småsamfundsgruppens arbete. Därför var det naturligt att till att börja med sätta dessa områden i fokus i projektet, samt även Grönland, som har en unik status i det nordiska samarbetet även om de inte har varit representerade i Småsamfundsgruppen. Ämnet kan vara aktuellt i fler mindre samhällen i Norden, t.ex. på enskilda öar och i samhällen längst i norr i Sverige och Finland. Dessa anses dock ha liknande förutsättningar som Nordnorge när det gäller Svanen.

Ovannämnda områden kan i stora drag delas upp i fyra kategorier vad gäller tillgång till Svanensekretariat. Färöarna och Grönland är självstyrda områden som hör till Danmark och har förhållandevis låga invånarantal. Dessa områden ligger långt borta från den administrativa centralen i Köpenhamn samt från den nordiska och internationella marknaden. Åland har en liknande politisk status som en självstyrd del av Finland, men där är de geografiska avstånden små. Island har i princip samma förutsättningar som de fyra "stora" nordiska länderna, men med ett mycket lägre invånarantal. Nordnorge är slutligen bara en del av Norge, med aningen otydliga gränser. 


\subsection{Metoder}

Projektet är delvis en skrivbordsutredning, delvis en insamling av kunskap och kommentarer från relevanta aktörer på nordisk och nationell nivå, t.ex. från de nationella miljömärkningssekretariaten och från ett antal företag i mindre samhällen i Norden.

\subsection{Rapportens struktur}

Denna rapport är indelad i fyra delar. Först ges en översikt över Svanens avgiftsstruktur i kapitel 2. Kapitel 3 innehåller en översikt över Svanens status i enskilda områden som omfattas av rapporten. I kapitel 4 diskuteras de viktigaste aspekterna som framkommit och påverkar utvecklingen av Svanen. Rapportens huvuddel är kapitel 5 där ett antal rekommendationer presenteras ang. riktlinjer och åtgärder för att öka antalet Svanenmärkta företag (varor/tjänster) i mindre samhällen i Norden. Här finns även en beskrivning av hur detta arbete kan organiseras och finansieras. 


\section{Avgiftsstruktur}

Svanens avgiftsstruktur är en viktig fråga när det gäller intresset för Svanen i små företag och samhällen. Svanen har en liknande avgiftsstruktur i de fem nordiska länderna, med något varierande belopp. För att förenkla för företag att sälja Svanenmärkta produkter på hela den nordiska marknaden utvecklas nu ett gemensamt avgiftssystem, Nordisk avgiftsgrupp (NAG). Vissa produktgrupper har redan upptagits i NAG-systemet, vilket innebär att varje licens automatiskt blir en nordisk licens och att den berörda produkten inte behöver registreras för att säljas i andra nordiska länder. Producenten måste däremot meddela Nordisk Miljömärkning om vilka länder han/hon avser sälja sin produkt i och fortsatt rapportera omsättningen uppdelad per nordiskt land. ${ }^{2}$ Till följd av denna utveckling blir skillnaden i avgifter mellan länder allt mindre.

\subsection{Ansökningsavgift}

En ansökningsavgift betalas till miljömärkningssekretariatet i hemlandet när ett företag ansöker om en Svanenlicens. Enligt information på sekretariatens hemsidor är denna avgift 13 700-17 300 DKK (utan moms) per land. Avgiften avser handläggning av ansökan, granskning av bifogad dokumentation samt ett kontrollbesök hos sökanden som görs i samband med att licensen beviljas. För utvidgning eller förnyelse av licensen betalas en halv ansökningsavgift. 3,4,5,6,7

Mikroföretag får 50 \% rabatt på ansökningsavgiften samt på utvidgnings-/förnyelsesavgiften. I detta sammanhang definieras ett mikroföretag på samma sätt som inom EU, dvs. ett företag med högst 10 medarbe-

\footnotetext{
2 Miljömärkning Sverige AB (2012): Vad kostar det? http://svanen.se/Foretag/avgifter 3 Ibid.

${ }^{4}$ Miljømærkning Danmark (2012): Hvad koster det at få et miljømærke?

http://www.ecolabel.dk/producenter/Hvad+koster+det+at+faa+et+miljoemaerke 5 Miljømerking (2012): Hva kostar det?

http://www.svanemerket.no/for-bedrifter/sok-om-svanemerket/avgifter

${ }^{6}$ Ecolabel Finland (2012): Creating the future now. http://www.ecolabel.fi/ymparistomerkki/in_english

7 Umhverfisstofnun (2012): Kostnaður. http://www.ust.is/atvinnulif/svanurinn/kostnadur
} 
tare och en omsättning på högst 2 millioner euro (14,9 millioner DKK). En stor andel av företagen i mindre samhällen i Norden omfattas av denna definition.

\section{2 Årlig licensavgift}

När licensen är beviljad tillkommer en årsavgift baserad på den Svanenmärkta produktens omsättning. Licensavgiften varierar mellan olika produktgrupper, men den vanligaste avgiften för produkter är 0,3 \% av omsättningen, ofta med ett minimum- och maximumbelopp. Minimumavgiften varierar mellan de olika länderna, från ca 2300 DKK på Island till ca 11200 DKK i Finland. På samma sätt varierar maximumavgiften från ca 115000 DKK till ca 255000 DKK. Licensavgiften för tjänster är allmänt lägre, cirka 0,15 \%. Speciella bestämmelser gäller för vissa tjänster, t.ex. för tryckerier vars årliga licensavgift baseras på pappersförbrukning. Här finns det också min- och maxavgifter.

I framtiden kommer det nordiska avgiftssystemet (NAG-systemet) att ersätta de nationella systemen i takt med att reviderade kriterier kommer att antas för varje produktgrupp. Licensavgiften kommer då att beräknas utifrån den totala omsättningen av försålda Svanenmärkta produkter i hela Norden.

\subsection{Speciella bestämmelser för småföretag}

Småföretag får generellt ingen särbehandling vad gäller avgifter till Svanen, utöver 50 \% rabatt på ansökningsavgift samt på utvidgnings/förnyelsesavgiften som beskrivit ovan. Generellt måste också samtliga företag behandlas på samma sätt enligt paragraf 5.16 i standarden ISO $14024 .{ }^{8}$

Brist på tid och mänskliga resurser kan vara ett stort hinder i småföretagens arbete med Svanen, medan de större företagen har bättre möjligheter att utbilda sin personal och har mer tid för miljöarbete. I praktiken leder detta till att Svanenmärkning av små producenter kräver en förhållandevis större arbetsinsats från Svanensekretariatens sida, ef-

${ }^{8}$ ISO (International Organization for Standardization), (1999): International Standard ISO 14024. Environmental labels and declarations - Type I environmental labelling - Principles and procedures. ISO 14024:1999(E). ISO, Schweiz. 
tersom sekretariaten alltid strävar efter att ge en så god service som möjligt. Ett mindre företags licens kan med andra ord betyda mer arbete och samtidigt mindre intäkter än en stort företags licens. Svanensekretariatet i Oslo (Miljømerking Norge) har utvecklat ett system för detta där de utbildar Svanenkonsulter. De producenter som anlitar godkända Svanenkonsulter betalar endast halv ansökningsavgift. ${ }^{9}$ Detta är en "win-win situation" eftersom det också sparar en hel del arbete för sekretariatet.

Kontrollbesök till avlägset belägna företag, oavsett företagens storlek, brukar vanligtvis vara dyrare, både i arbetstid och omkostnader. Detta avspeglas inte i ansökningsavgiften, men betyder i praktiken att sekretariatens ekonomi blir allt sämre om en större andel företag ligger långt borta.

\subsection{Exempel på ekologisk certifiering}

Tún är Islands enda kontrollorgan för inspektion och certifiering av ekologisk produktion i enlighet med nationella regler och EU:s förordningar. Eftersom det inte finns några godkända kontrollorgan på Färöarna och Grönland har Tún också hjälpt till i dessa områden. På Grönland har ingen producent uppnått certifiering, men på Färöarna har en gård samt ett förädlingsföretag certifierats av Tún. Här uppstår det samma problem som när det gäller Svanen, d.v.s. att resekostnader i anslutning till kontrollbesök blir mycket högre än inom Island. När det gäller enskilda gårdar inkluderar Tún resekostnader i sina certifieringsavgifter, vilket betyder att eventuella extrakostnader inte avspeglas i Túns fakturering. Däremot debiteras kostnader för flyg och hyrbilar när det gäller förädlingsföretag. Detta innebär att förädlingsföretag utanför Island betalar ett avsevärt högre pris för kontrollbesöken. Detta har man försökt jämna ut genom att lära upp kontrollpersoner i de mest avlägsna områdena, men detta har visat sig vara svårt p.g.a. begränsade resurser samt intressekonflikter som ofta uppstår i små samhällen. Generellt ser dock Tún detta som ett bra alternativ i stället för att etablera självständiga kontrollorgan i länder/områden med ett mycket begränsat antal kunder.10

\footnotetext{
${ }_{9}^{9}$ Alvhild Hed stein, Miljømerking Norge: E-post 14 nov 2012.

${ }^{10}$ Gunnar Á. Gunnarsson, Tún: Telefonsamtal 4 jan 2013.
} 



\section{Status i enskilda områden}

Denna rapport handlar främst om Småsamfundsgruppens geografiska arbetsområde, d.v.s. Island, Färöarna, Åland och Nordnorge samt Grönland. Detta avsnitt innehåller en kort översikt över Svanens status i dessa fem områden.

I nuläget finns det kriterier för Svanenmärkning av 61 olika produktgrupper. ${ }^{11}$ Endast ett begränsat antal av dessa är aktuella i det här sammanhanget, och som framkommit tidigare finns det bortsett från fiskeindustrin förhållandevis få tillverkningsindustrier i de berörda områdena. Däremot finns det många olika serviceföretag, inte minst inom turistbranschen, där miljömärkning borde vara högst aktuell, särskilt $\mathrm{i}$ ljuset av hur beroende turistbranschen är av oförstörd natur.

Tabell 1 visar en ungefärlig uppskattning av antalet företag inom aktuella produktgrupper och andelen företag som fått Svanen (Sv i tabellen) för sina produkter eller tjänster. Nordnorge tas inte med i denna uppskattning eftersom det varit svårt att skilja mellan företag i olika landsdelar.

11 Miljömärkning Sverige AB (2013): Kriterier. http://www.svanen.se/Foretag/Kriterier 


\begin{tabular}{|c|c|c|c|c|c|c|c|c|}
\hline \multirow[t]{2}{*}{ Produktgrupp } & \multicolumn{2}{|c|}{ Island } & \multicolumn{2}{|c|}{ Färöarna } & \multicolumn{2}{|c|}{ Åland } & \multicolumn{2}{|c|}{ Grönland } \\
\hline & Antal & Sv & Antal & Sv & Antal & Sv & Antal & Sv \\
\hline Dagligvarubutiker & 270 & 0 & 19 & 0 & 27 & 0 & 115 & 0 \\
\hline Digital fotoframkallning & 10 & 0 & 0 & 0 & 2 & 0 & 0 & 0 \\
\hline Fordonstvätt & 10 & 0 & 2 & 0 & 4 & 1 & 0 & 0 \\
\hline Hotell och vandrarhem & 320 & 5 & 27 & 0 & 25 & 1 & 28 & 0 \\
\hline $\begin{array}{l}\text { Industriella rengörings- och } \\
\text { avfettningsmedel }\end{array}$ & 10 & 1 & 1 & 0 & 0 & 0 & 0 & 0 \\
\hline Restauranger & 370 & 3 & 61 & 0 & 81 & 0 & 43 & 0 \\
\hline Städtjänster & 25 & 6 & 12 & 0 & 12 & 0 & 5 & 0 \\
\hline Textilier, skinn och läder & 15 & 0 & 3 & 0 & 3 & 0 & 0 & 0 \\
\hline Tryckerier & 85 & 10 & 11 & 2 & 6 & 2 & 0 & 0 \\
\hline Tvätterier/ Textilservice & 65 & 0 & 6 & 0 & 3 & 0 & 5 & 0 \\
\hline TOTALT & 1180 & 25 & 142 & 2 & 163 & 4 & 196 & 0 \\
\hline
\end{tabular}

Uppgifterna i tabellen har hämtats från olika källor, t.ex. tillgängliga företagsregister och databaser, nationella "gula sidor", nationella marknadsföringssidor, regionala informationssidor, sidor med turistinformation m.m.

Som framgår av tabell 1 finns det stor potential för Svanenmärkning i de berörda länderna/områdena. Det bör understrykas att siffrorna i tabellen inte är exakta, men de ger åtminstone en grov bild av antalet företag inom de sektorer som uppfattas som mest aktuella. Den största potentialen ligger som förväntat inom tjänstesektorn, speciellt hotell, restauranger och dagligvarubutiker. Tryckerier, städtjänster och tvätterier har också en förhållandevis stor potential att bli Svanenmärkta.

\subsection{Island}

Generellt verkar Svanen ha uppnått en stark ställning på Island efter stora framgångar under de senaste fyra åren. Innan dess rådde ett slags stillestånd under flera år. I slutet av år 2002 fanns det t.ex. endast fyra Svanenlicenser i Island. De var fortfarande fyra i slutet av år 2008 och 
fem i slutet av 2009.12 Detta antal ökade till 23 till slutet av 2012, d.v.s. mer än femdubblades på fyra år. Ytterligare två licenser godkändes under första kvartalet 2013.

Ingen vetenskaplig undersökning har gjorts av succéfaktorerna bakom Svanens snabba framgång på Island under de senaste åren. Tre faktorer har dock nämnts som huvudsakliga förklaringar av detta: ${ }^{13}$

- Politisk vilja

Svanens framgång på Island anses delvis vara en konsekvens av målinriktat arbete inom den isländska miljömärkningsnämnden och Umhverfisstofnun (Miljöverket), som fungerar som det isländska Svanensekretariatet. År 2008 fick Umhverfisstofnun en ny chef och samma år anställdes för första gången en medarbetare på heltid för att jobba med Svanen. Detta ser ut att ha spelat en stor roll för utvecklingen. I början av 2009 fick Island också en ny regering som lade större vikt på grön ekonomi än den föregående. Detta kan också ha bidragit, trots att det inte avspeglas direkt i befintliga dokument. Svanen finns fortfarande inte som en självständig post i statsbudgeten utan ingår i Umhverfisstofnuns årliga budget. Satsningen verkar ha skett främst inom institutet genom nya prioriteringar.

- Grön offentlig upphandling Sedan år 2009 har isländska myndigheter haft en fungerande riktlinje om grön offentlig upphandling som genomförts inom ramen för ett pågående projekt i samarbete med miljömyndigheter och inköpare i offentliga inrättningar på stats- och kommunnivå. ${ }^{14}$ Nya krav på miljöanpassade tjänster har skapat stark efterfrågan, särskilt när det gäller rengörings- och tryckeritjänster. Av denna erfarenhet borde man kunna dra lärdomar som kan användas i övriga områden.

- Ekonomisk nedgång

Den ekonomiska nedgången hösten 2008 har möjligen bidragit till en ökad satsning på miljömärkning inom vissa sektorer. En minskad efterfrågan på varor och tjänster ledde antagligen till en hårdare konkurrens, samtidigt som offentlig sektor blev en ännu viktigare kund parallellt med nedgången i privata konsumtion.

\footnotetext{
12 Umhverfisstofnun (2013): Sjálfbært samfélag. Svansleyfi.

http://www.ust.is/einstaklingar/astand-umhverfisins/sjalfbaert-samfelag

13 Elva Rakel Jónsdóttir, Umhverfisstofnun: Telefonsamtal 14 nov 2012 och 15 april 2013.

14 Vistvæn innkaup (Grön upphandling) (2013). Hemsida. http://www.vinn.is
} 
Svanen är inte lika stark i glesbygden som i Reykjavikområdet, men skillnaden är inte större än förväntat. Av 25 Svanenlicencer på Island har sex (24 \%) hemort utanför huvudstadsområdet. De största företagen och de som konkurrerar i offentliga anbud ligger för det mesta i huvudstadsområdet, och där bor hela $64 \%$ av Islands befolkning. Andra områden har alltså $36 \%$ av befolkningen, $24 \%$ av Svanenlicenserna och en väldig liten del av de största företagen. Det verkar därmed som om det inte finns behov av specifika åtgärder för att stödja en vidare utveckling av miljömärkningen i mindre samhällen på Island, utan snarare bland småföretag, oavsett belägenhet.

Som ett självständigt medlemsland i Nordiska ministerrådet skiljer sig Island från Färöarna, Grönland och Åland vad gäller miljömärkning. På Island har Svanen formell och rättslig status som ett officiellt miljömärke och där har Svanen ett nationellt miljömärkningssekretariat. Företag på Färöarna, Grönland och Åland måste däremot lita på service från de nationella sekretariaten i Danmark resp. Finland, samt när det gäller Åland i vissa fall också Sverige.

\subsection{Färöarna}

Färöarna har inte samma förutsättningar som Island när det gäller miljömärkning, delvis p.g.a. en annorlunda politisk struktur och delvis p.g.a. ett lägre invånarantal. Bortsett från fiskeindustrin finns det också förhållandevis få tillverkningsindustrier på Färöarna, samtidigt som det inte råder någon större konkurrens mellan dessa. Däremot finns det många olika serviceföretag, inte minst inom turistbranschen, för vilka miljömärkning borde vara högst aktuell med tanke på hur beroende turistbranschen är av oförstörd natur. Miljömärkning av serviceföretag kräver inte heller lika mycket arbete med tekniska detaljer som märkning av vissa industrier, där det har visat sig vara svårt att få fram tillräcklig detaljerad information från leverantörerna om de olika råvarornas innehåll och egenskaper. ${ }^{15}$

Under perioden 2007-2012 var Føroyaprent det enda företaget på Färöarna som hade fått Svanen för sina produkter eller tjänster. Enligt Jon Hestoy, företagets VD, var detta ingen tung process för dem, även om

\footnotetext{
15 Nordiska ministerrådet (2012): Svanen och EU Ecolabel. Succéhistorier i nordiska småsamfund. Nordiska ministerrådet, Köpenhamn. http://www.norden.org/sv/publikationer/publikationer/2012-553
} 
information och service måste sökas från Svanensekretariatet i Köpenhamn. Däremot kan det, enligt Jon, vara svårare för nykomlingar att komma igång, eftersom Svanen inte har någon "hemmaplan" på Färöarna. Det förekommer inga direkta reklam- eller informationskampanjer på Färöarna. Svanen är dock mycket synlig på dansk TV, vilket innebär en viss marknadsföring, även om den inte drivs av myndigheterna. ${ }^{16}$ Jon Hestoy har sagt att han inte alls förstår "varför det inte finns fler som söker om miljömärkning. Det skulle säkert hända om det fanns någon som var smart nog att informera om hur lätt det faktiskt är" ${ }^{17}$ Ett annat tryckeri på Färöarna, Estra/Vasti, fick Svanenlicens i augusti 2012 via sekretariatet i Köpenhamn.18,19

Det finns ett stort antal Svanenmärkta varor i färöiska butiker. ${ }^{20}$ Därför kan man räkna med att färöiska konsumenter känner igen märket, även om det inte finns någon undersökning som bekräftar detta. Märkets synlighet har antagligen också en viss konkurrensmässig betydelse. Det kan förväntas att Svanenmärkta produkter får ett konkurrensmässigt försprång, särskilt i tider när konsumenternas miljömedvetenhet ökar. Samtidigt riskerar inhemska producenter att halka efter om de inte kan erbjuda miljömärkta alternativ inom produktgrupper där miljömärkta varor finns.

Enligt kontaktpersoner på Färöarna finns det en viss efterfrågan på miljömärkning från näringslivets sida, både inom turistindustrin och hos tryckerier, städfirmor och producenter av rengöringsmedel.21,22 Denna efterfrågan har dock inte nått fram till miljömyndigheterna, vilket kan bero på att det formellt sett inte finns någon mottagare inom det offentliga för en sådan efterfrågan. Miljömärkning ingår inte formellt i myndigheternas uppgifter och ingen har till uppgift att ta emot förfrågningar och sprida information angående detta. Miljömärkningssekretariatet i Köpenhamn har inte heller märkt någon efterfrågan från färöiska företag. 23

Det pågår arbete i finansministeriets regi med utveckling av offentliga inköpsregler på Färöarna, men det finns fortfarande ingen offentlig

\footnotetext{
16 Ibid.

17 Ibid., s. 35.

${ }^{18}$ Estra/Vasti (2012): Estra/Vasti svanamerkt prentsmiðja. Nyhet på hemsida 23 oktober 2012.

http://estra.fo/tiacuteethindi/57-estravasti-svanamerkt-prentsmiethja/\#57

19 Maria Gunnleivsdóttir Hansen, Umhvørvisstovan: E-post 5 feb 2013.

${ }^{20}$ Anni á Hædd, Inrikesministeriet Tórshavn: Telefonsamtal 15 april 2013.

21 Ibid.

22 Jóhanna Zachariasen, Kemilux: E-post 30 nov 2012

${ }^{23}$ Tine Due Hansen och Lisbeth Engel Hansen, Miljømærkning Danmark: E-post 9 jan 2013.
} 
riktlinje för grön offentlig upphandling. Detta kommer möjligen att tas upp när de grundläggande inköpsreglerna fastställts. ${ }^{24}$

Det bör understrykas att Svanen inte har rättslig status som ett officiellt miljömärke på Färöarna. I Danmark regleras miljömärkning av "Miljøbeskyttelsesloven"25 samt av Miljöministeriets regler om det europeiska och det nordiska miljömärket, ${ }^{26}$ vilka baseras på Miljøbeskyttelsesloven. Av lagens paragraf $\S 118$ framgår att lagen inte gäller för Färöarna och Grönland. Färöarna har heller ingen egen lagstiftning om Svanen eller miljömärkning i övrigt.

\subsection{Grönland}

Grönland har formellt en liknande status som Färöarna, både ur politisk synpunkt och mätt i invånarantal. Grönlands befolkning är däremot mycket utspridd på ett enormt geografiskt område samt ibland också etniskt och språkmässigt uppdelat med ca $10 \%$ nordisk befolkning och 90 \% grönländsk. Detta, tillsammans med ett stort avstånd till den administrativa centralen i Köpenhamn samt från den nordiska marknaden, gör att det antagligen är svårare för Svanen att få fotfäste i Grönland än i övriga självstyrda områden i Norden. Hittills har inget företag på Grönland ansökt om Svanenlicens eller överhuvudtaget varit i kontakt med Svanensekretariatet i Danmark. ${ }^{27}$ Enligt information från Miljöavdelningen och Naturavdelningen inom Grönlands Självstyre har de heller inte fått ärenden eller förfrågningar om Svanen eller miljömärkning, varken från allmänheten eller från producenter av varor och tjänster. ${ }^{28}$

Sannolikt skulle Svanen framför allt vara aktuell inom turistindustrin på Grönland, men den enda kommentar som framkommit från grönländska företag i denna utredning ger inga indikationer på att det finns efterfrågan från kunder eller att företagen känner behov för mil-

\footnotetext{
${ }^{24}$ Anni á Hædd, Inrikesministeriet Tórshavn: Telefonsamtal 15 april 2013.

${ }^{25}$ Retsinformation.dk (2010): Bekendtgørelse af lov om miljøbeskyttelse. LBK nr 879 af 26/06/2010. Miljø-

beskyttelsesloven. Offentliggørelsesdato: 09-07-2010. Miljöministeriet, Danmark.

https://www.retsinformation.dk/Forms/r0710.aspx?id=132218

${ }^{26}$ Retsinformation.dk (2010): Bekendtgørelse om det europæiske og det nordiske miljømærke. BEK nr 447 af 23/04/2010. Offentliggørelsesdato: 30-04-2010. Miljöministeriet, Danmark.

https://www.retsinformation.dk/Forms/R0710.aspx?id=131387\&exp=1

27 Tine Due Hansen och Lisbeth Engel Hansen, Miljømærkning Danmark: E-post 9 jan 2013.

28 Uiloq Mulvad Jessen, Grönlands Självstyre: E-post 12 nov 2012.
} 
jömärkning, även om de försöker vara så miljömedvetna som möjligt i sin verksamhet. 29

Utöver turistindustrin är tryckerier och städtjänster antagligen de sektorer som främst skulle gagnas av Svanen i ett marknadsområde som Grönland, med få tillverkningsindustrier och mycket låga försäljningsvolymer. Det stora avståndet från den nordiska och internationella marknaden gör att det endast finns begränsade möjligheter för export, samtidigt som det är svårt för inhemska företag att konkurrera mot import av varor och tjänster som tillverkas i en mycket större skala. Ett exempel på detta är att man inte har lyckats bygga upp konkurrenskraftiga tryckerier på Grönland. Ett försök i denna riktning gjordes för några år sedan av Naqitat A/S, men deras tryckeri stängdes redan våren 2012 p.g.a. ekonomiska svårigheter. De kunde enligt grönländsk media inte konkurrera med utländska tryckerier. ${ }^{30}$

För Grönland gäller detsamma som för Färöarna, att Svanen inte har någon rättslig status som officiellt miljömärke enligt den danska "Miljøbeskyttelsesloven" (se ovan).

\section{4 Åland}

Åland har politiskt sett liknande status som Färöarna och Grönland, men invånarantalet är något lägre. Åland ligger däremot nära sina grannar i Finland och Sverige, geografiskt.

På Åland finns det i nuläget fyra företag som fătt Svanen för sina produkter eller tjänster, ett hotell, två tryckerier och en biltvätt. Tre av dessa har bidragit till denna utredning. De är eniga om att arbetet med Svanen har gått smidigt, nöjda med den service som de får från sekretariaten i Stockholm och Helsingfors och anser att det inte behövs något ytterligare för att underlätta deras arbete. Enligt Michael Terry på TidningsTryckarna, som är ett av de fyra Svanenmärkta företagen, kunde man ha cirka 10 gånger fler licenser på Åland om man marknadsfört Svanen bättre. TidningsTryckarna har själva gjort enkätundersökningar och kommit fram till att intresset är stort hos befolkningen och hos småföretagen, men det krävs insatser för att aktivera den kraft som finns. Det är enligt Michael alltså inte de Svanenmärkta företagen som behöver

\footnotetext{
${ }_{29}$ Marianne Holdgaard Rasmussen, Hotel Hans Eged e: E-post 8 jan 2013.

${ }^{30}$ Sermitsiaq (2012): Naqitat kaster håndklædet i ringen. Nyhet 30 april 2012.

http://sermitsiaq.ag/node/124937
} 
stöd, utan de som inte har Svanen, är omedvetna eller inte vet hur man kommer igång. 31

Ett antal icke-Svanenmärkta företag på Åland har redan visat intresse för att söka Svanenlicens, både tillverkningsföretag och serviceföretag. 32,33 Generellt har företagen inte tagit kontakt med myndigheterna,34 utan antingen varit i kontakt med Svanensekretariatet i Stockholm eller Helsingfors. Åland hör till Finland, men företagen kan fritt välja vilket sekretariat de kontaktar. För många är det mer naturligt att söka Svanen från miljömärkningssekretariatet i Sverige än i Finland, eftersom Åland är ett enspråkigt svenskt område och endast drygt $5 \%$ av befolkningen i Finland har svenska som modersmål. 35 Det går dessutom dagligen ett antal färjor mellan Åland och Stockholm och resekostnaderna är rimliga. I detta sammanhang har Åland lika bra förutsättningar som vilket område som helst i Sverige.

Finland har ingen nationell lagstiftning om miljömärkning och inte heller Åland har någon lagstiftning om miljömärkning. Därmed har Åland samma förutsättningar som "fastlandet" i detta sammanhang.

\subsection{Nordnorge}

Ingen speciell granskning av situationen i Nordnorge ingick i denna utredning, men i Norge gäller i princip detsamma som på Island, d.v.s. att alla företag har lika goda möjligheter att kommunicera med Svanensekretariatet, oberoende av belägenhet. Här handlar det dock om mycket större avstånd och därmed högre resekostnader, både för företagen och för sekretariatets medarbetare. Svanen i Norge har redan gjort det lite lättare för småföretag att komma $\mathrm{i}$ gång genom att de som anlitar godkända Svanenkonsulter får 50 \% rabatt på ansökningsavgiften (se ovan).

Utöver geografiska avstånd finns det i Norge också i vissa fall språkliga avstånd när det gäller den samiskspråkiga delen av befolkningen samt invandrare. Samiska, huvudsakligen nordsamiska, talas av ca 0,4 \% av Norges befolkning, och nordsamiska har rättslig status som offentligt språk i 6 kommuner i Finnmark och Troms i Nordnorge. ${ }^{36}$

\footnotetext{
31 Michael Terry, TidningsTryckarna (2012): Telefonsamtal 27 nov 2012.

32 Ragnar Unge, Miljömärkning Sverige: E-post 25 okt 2012.

33 Kirsi Auranmaa, Miljömärkning Finland: E-post 21 nov 2012.

34 Mona Kårebring-Olsson, Ålands landskapsregering: E-post 15 april 2013.

35 Folktinget - Svenska Finlands folkting (u.d): Svenskan i Finland. http://www.folktinget.fi/sve/svenskan

${ }^{36}$ Store norske leksikon (u.d): Språk i Norge. http://snl.no/Norge/spr\%C3\%A5k
} 


\section{Diskussion}

\subsection{Rättslig status}

Som framkommit har Svanen ingen rättslig status som ett officiellt miljömärke på Färöarna och Grönland. I Danmark finns det nationella lagar och förordningar om miljömärkning, i vilka det tydligt anges att lagen inte gäller Färöarna och Grönland. Detta kan tolkas som att Svanen har reglerats ut. Finland har ingen lagstiftning om miljömärkning och inte heller Åland har lagstiftat om detta. ${ }^{37}$

Det faktum att Svanen inte har formell och rättslig status på Färöarna och Grönland behöver inte vare ett hinder för att Svanen får fotfäste i dessa områden. Däremot kan det ifrågasättas i vilken mån miljömärkningssekretariatet i Köpenhamn är förpliktigat att tillhandahålla service till dessa områden. Delvis kan situationen jämföras med producenter utanför Norden som kan välja att ansöka om Svanen från vilket nordiskt miljömärkningssekretariat som helst. Det verkar som sagt inte finnas någon grund för att avvisa ansökningar från de självstyrda områdena, även om de inte täcks av eventuella lagar om miljömärkning. Företag utanför Norden betalar 500 euro extra för kontrollbesök och företag utanför EU 1000 euro extra. Dessa extrakostnader får dock inte påläggas ansökande företag i de självstyrda områdena eftersom de hör till Norden.

Utifrån detta kan man dra slutsatsen att brist på rättslig status inte borde vara något stort hinder för att sprida Svanen i de självstyrda områdena.

\subsection{Efterfrågan}

Sekretariaten har inte märkt någon specifik efterfrågan från producenter i de självstyrda områdena eller övriga områden som uppfattas som mindre samhällen p.g.a. av sin lokalisering/isolering och som överväger att få sina varor eller tjänster Svanenmärkta. Generellt verkar intresset

37 Björn-Erik Lönn, Nordisk koordinator för Svanen: Telefonsamtal 16 jan 2013. 
från mindre samhällen vara lågt enligt sekretariaten. Inga stora slutsatser kan dock dras av detta förrän frågan utforskats i mer detalj. En låg efterfrågan kan bero på att företagen inte upplever miljömärkningssekretariatens service som tillgänglig p.g.a. geografiskt eller språkligt avstånd. Island är ett undantag i detta sammanhang, eftersom man där redan har delat ut sex certifikat till företag utanför huvudstadsområdet (av totalt 25 certifikat), vilket är någorlunda i linje med det som skulle förväntas med hänsyn till invånarantalet och antalet licenser i huvudstadsområdet.

En annan möjlig förklaring till en upplevd låg efterfrågan från företag i små samhällen kan vara att deras kunder inte kräver något bevis på miljöarbetet. Dessa företag har i så fall inte samma konkurrensmässiga drivkrafter som företag med ett nationellt eller internationellt marknadsområde. Svanenmärkning är attraktivt som ett konkurrensmedel, men då måste det finnas någon som företagen konkurrerar med. Här beror situationen dock på branschen. T.ex. ser Føroyaprent, det ena av två Svanenmärkta företag på Färöarna, miljömärkning som ett mycket viktigt konkurrensverktyg. ${ }^{38}$ Tryckning kan utan besvär köpas från andra länder, vilket betyder att små tryckerier riskerar att mista en del av sina kunder om de inte kan bevisa att de erbjuder minst samma kvalitet och tillförlitlighet som utländska konkurrenter. En liknande situation kan uppstå inom fler sektorer när konsumenterna börjar bli mer miljömedvetna, samtidigt som importerade miljömärkta varor och tjänster blir allt mer tillgängliga.

Det finns tecken på att producenter i små samhällen som kontaktar miljömärkningssekretariaten gör det för att stora kunder, t.ex. köpare av trycksaker och möbler, kräver att alla leverantörer har Svanen, eller att t.ex. hotell- eller butikskedjor har bestämt att hela kedjan ska Svanenmärkas.

Nationella miljömyndigheter i de självstyrda områdena har en liknande erfarenhet som miljömärkningssekretariaten vad gäller efterfrågan på information och service i anslutning till Svanen. Det verkar finnas en viss efterfrågan, men den når inte fram till myndigheterna, vilket kan bero på att det formellt sett inte finns någon mottagare inom det offentliga för en sådan efterfrågan.

På de nationella miljömärkningssekretariaten ser man inte något stort behov av generella/specifika åtgärder för att stödja en vidare ut-

\footnotetext{
38 Nordiska ministerrådet (2012): Svanen och EU Ecolabel. Succéhistorier i nordiska småsamfund. Nordiska ministerrådet, Köpenhamn. http://www.norden.org/sv/publikationer/publikationer/2012-553
} 
veckling av miljömärkningen i mindre samhällen. Däremot kan det finnas behov av en extra insats bland minoritetsbefolkningen, d.v.s. samer och invandrare. Behovet i mindre samhällen är dock antagligen en typisk "ägg-eller-höna-fråga", d.v.s. att det inte kommer att finnas något stort behov förrän man skapat efterfrågan.

\subsection{Avgifter}

Som framgår av kapitel 2 betalar både små och stora företag en ansökningsavgift när de ansöker om en Svanenlicens. Detta är ett fast belopp, men mikroföretag får $50 \%$ rabatt. När licensen är beviljad tillkommer en årsavgift baserad på den Svanenmärkta produktens omsättning.

Representanter från de Svanenmärkta företagen som bidragit till "succéhistorierna" ansåg generellt inte att avgifterna till Svanen var något hinder. Flera av dessa konstaterade tvärtom att avgifterna var rimliga i förhållande till de tjänster och den publicitet man får.

Utifrån föreliggande information och enskilda kommentarer från småföretag ser avgifter till Svanen alltså inte ut att vara något hinder för en vidare utveckling av Svanen i mindre samhällen. Rabatt för mikroföretag samt det norska initiativet med Svanenkonsulter bidrar också till detta. Någon extra sänkning av avgifter för småföretag i avlägsna områden verkar inte vara ett realistiskt alternativ. De har i detta sammanhang liknande förutsättningar som övriga småföretag, med undantag av resekostnader. Miljömärkningssekretariatens resekostnader i samband med kontrollbesök ingår i den fasta ansökningsavgiften. Däri ligger en automatisk likställdhetsmekanism.

\subsection{Extrakostnader}

Det finns tillfällen då småföretag eller företag i mindre samhällen har visat intresse för och möjligen kommit igång med att förbereda Svanenmärkning av sina varor eller tjänster, men sedan avbrutit detta eller inte hunnit. Däremot finns det inga tecken på att detta hänger ihop med företagens belägenhet eller samhällenas begränsade storlek.

Som framkommit finns det, bortsett från fiskeindustrin, inte många tillverkningsföretag i mindre samhällen i Norden. De som finns producerar ofta ett flertal produkt i mycket små volymer. I situationer där produkten hör till olika produktgrupper och därför måste uppfylla olika kriterier för att kunna Svanenmärkas kan det hända att samma företag 
behöver ansöka om flera licenser och därmed betala flera licensavgifter (en per produktgrupp). Detta kan i vissa fall vara ett hinder.

Miljömärkning av småföretag i mindre samhällen kan förväntas medföra förhållandevis höga kostnader för miljömärkningssekretariaten, eftersom kontrollbesök i avlägsna samhällen kräver mer tid och medför högre resekostnader. Samma problem förekommer uppenbarligen inom övriga certifieringsordningar, vilket framgår av exemplet Tún i kapitel 2.4. Tún har delvis löst problemet genom att debitera kostnader för flyg och hyrbilar när det gäller förädlingsföretag i utlandet. Det rekommenderas dock inte att Svanen följer detta exempel, eftersom företag i olika delar av Norden i princip borde ha samma tillgång till Svanen. Problemet med dyra kontrollbesök borde snarare lösas med en generell mindre höjning av årsavgiften eller genom speciella offentliga bidrag. Detta kan dock vara en känslig fråga ur konkurrenssynpunkt. En annan lösning vore att utbilda kontrollpersoner i de mest avlägsna områdena, men detta är knappast realistiskt med tanke på Svanenkriteriernas mångfald och sektorspecifika innehåll.

\subsection{Marknadsföring}

De nationella miljömärkningssekretariaten har inte gjort något speciellt för att marknadsföra Svanen i de mindre samhällena, t.ex. genom kampanjer, varken i de självstyrda områdena (Färöarna, Grönland och Åland) eller i övrigt, utöver det som gjorts generellt. Ett undantag är ett initiativ på Åland omkring år 2005 när miljömärkningssekretariatet i Finland stod för ett informationsmöte med anställda hos landskapsregeringen samt besök på företag. ${ }^{39}$ Enligt information från sekretariaten har denna typ av service generellt inte diskuterats eller efterfrågats. Det kan också ifrågasättas i vilken mån marknadsföring av Svanen i de självstyrda områdena ingår i de nationella miljömärkningssekretariatens uppdrag, särskilt när det gäller det danska sekretariatet, som enligt lagen inte har någon formell roll när det gäller Färöarna och Grönland.

I ljuset av det som framkommer ovan kan man dra slutsatsen att myndigheterna i de självstyrda områdena har det primära ansvaret för marknadsföring av Svanen på hemmaplan. Eftersom miljömärkning inte ingår i myndigheternas dagliga uppgifter finns det dock antagligen endast be-

39 Mona Kårebring-Olsson, Ålands landskapsregering: E-post 15 april 2013. 
gränsad kompetens för detta på myndighetsnivå. För att komma vidare med detta behövs stöd, t.ex. från de nationella miljömärkningssekretariaten i något av de 5 "stora" nordiska länderna. En nordisk "roadshow" kunde vara ett lämpligt första steg i detta, t.ex. i form av en temadag i varje område, där man informerar om Svanen och miljömärkning i övrigt och samtidigt söker skapa en översikt över det aktuella intresset i det berörda området/landet. Nordiska medel skulle kunna användas för förberedelse och samordning av detta samt för ersättning för resekostnader, medan det lokala genomförandet kan finansieras med nationella medel. Om intresse finns kunde ett nästa steg vara mer sektorspecifikt och/eller riktat mot specifika kundgrupper, t.ex. småbarnsföräldrar. Modeller för sådana kampanjer finns i övriga länder, jämför t.ex. med den norska kampanjen"God start" samt "Ágætis byrjun" på Island. ${ }^{40}$

Mindre samhällen i de 5 "stora" länderna får sin del av den generella marknadsföringen, t.ex. i form av informationsbroschyrer och information i media, med undantag av samiskspråkiga områden och bland invandrare. För att komma vidare skulle det krävas mer medel för översättning av material. Detta innebär inte alls någon särbehandling som strider mot ISO 14024, utan är snarare en jämställdhetsfråga.

Trots att miljömärkningssekretariaten inte har gjort något speciellt för att marknadsföra Svanen i mindre samhällen har Svanen i någon mån marknadsförts i dessa områden genom att redan Svanenmärkta företag frivilligt har tagit på sig en roll som Svanen-ambassadörer. Exempel på detta är Føroyjaprent som arbetat mycket strukturerat med Svanen som varumärke, bl.a. genom en kampanj där deras kunder informeras om vikten av att köpa Svanenmärkt. ${ }^{41}$ TidningsTryckarna på Åland har också gjort en hel del för att informera om Svanenmärkningen, bl.a. genom att skicka ut frågeformulär till sina kunder. Föregångarens roll borde beaktas i detta sammanhang, för däri ligger eventuellt potential för att komma ett steg vidare.

Marknadsföring av Svanen har minst två olika målgrupper, å ena sidan företag och å andra sidan konsumenter. I områden där miljömedvetenheten är låg borde marknadsföringen antagligen fokusera på allmänheten för att skapa efterfrågan underifrån, medan företagen blir en allt mer viktig målgrupp med ökande miljömedvetenhet hos allmänheten. Olika målgrupper kräver olika metoder.

\footnotetext{
40 Umhverfisstofnun (2013): Ágætis byrjun.

http://www.ust.is/einstaklingar/umhverfismerki/svanurinn/agaetis-byrjun

${ }^{41}$ Nordiska ministerrådet (2012): Svanen och EU Ecolabel. Succéhistorier i nordiska småsamfund. Nordiska

ministerrådet, Köpenhamn. http://www.norden.org/sv/publikationer/publikationer/2012-553
} 


\subsection{Incitament}

Det finns inga specifika incitament för producenter i småbygder att ansöka om Svanen utöver det som gäller producenter generellt, med undantag för det norska miljömärkningssekretariatets initiativ med utbildning av konsulter (se kapitel 2.3). Detta är inte specifikt riktat till företag i mindre samhällen, men gagnar dessa i hög grad. Generellt kunde stöd till småproducenter ske t.ex. i form av extra konsulthjälp (som i den norska modellen), extra arbetsinsats från sekretariatens sida, o.s.v.

Det står klart att kostnaderna för speciell service från sekretariatens sida för företag i mindre samhällen i Norden skulle vara betydligt högre än för genomsnittet. Detta kräver längre resor och i de flesta fall också större förvaltningsinsats, både mätt i tid och pengar, då småföretagen generellt behöver mer hjälp med att fylla i ansökningar och olika blanketter. Därför kan sekretariaten knappast själva fatta beslut om specifika incentiv, utan detta måste vara en del av en större politisk satsning eller strategi. Det har också påpekats att när det gäller officiell miljömärkning enligt ISO 14024 kan sekretariatens kunder i princip inte behandlas på olika sätt.

Företag i enskilda områden/länder kan eventuellt söka medel från nationella stödprogram för att underlätta någon del av arbetet med Svanen. Som ett exempel kan nämnas att färöiska myndigheter årligen delar ut totalt 700000 DKK till olika miljöprojekt.42

\subsection{Undersökningar}

Man har inte tidigare har gjort någon undersökning av Svanens status i de mindre samhällena. I Norge kan man dock sortera resultaten från den generella undersökningen på fylker. Undersökningar av Svanens status i enskilda områden/länder skulle vara ett viktigt led i att identifiera styrkor, svagheter, möjligheter och hot och därmed skapa ett viktigt underlag för beslut om hur Svanen kan främjas i de olika områdena.

42 Anni á Hædd, Inrikesministeriet Tórshavn: Telefonsamtal 15 april 2013. 


\subsection{Språk}

Språket är en grundläggande fråga när det gäller spridning av miljömärkning i mindre samhällen, särskilt när det gäller Grönland, men i en viss mån även övriga bygder. På Grönland handlar det om att skapa liknande förutsättningar för miljömärkningen som i danskspråkiga områden. Detsamma gäller också i viss mån Färöarna, även om nästan alla där förstår och pratar tillräckligt bra danska. ${ }^{43}$

Möjligen är det inte realistiskt att bygga upp egna miljömärkningssekretariat på Färöarna, Grönland och Åland. Det är dock mycket viktigt att producenter av varor och tjänster har tillgång till den information de behöver på sitt eget språk. Brist på tillgängliga medel verkar vara ett stort hinder i detta sammanhang. För att producenter i hela Norden ska ha samma tillgång till information och service från Svanen oavsett språk, krävs tydliga riktlinjer och öronmärkta medel.

Det kan inte förväntas att översättning av material om Svanenmärkningen ska finansieras av nordiska medel, t.ex. av den Nordiska miljömärkningsnämnden (NMN). Ansvaret för detta måste ligga på nationell nivå. I princip handlar översättningsfrågan om två eller tre språk, d.v.s. färöiska, grönländska och eventuellt samiska. Den samiska delen borde skötas av norska myndigheter (när det gäller Nordnorge), medan översättningar till färöiska och grönländska antingen borde finansieras nationellt i de självstyrda områdena eller av Danmark, trots att Danmark inte har någon rättslig roll när det gäller miljömärkning på Färöarna och Grönland. Detta skulle också kunna ingå i Småsamfundsgruppens arbete, och stödjas med andra västnordiska medel när det gäller Island, Färöarna och Grönland.

\subsection{Upphandling}

Hållbar upphandling, både i offentlig och privat sektor, innebär outnyttjad potential när det gäller Svanens utveckling i mindre samhällen. Någon form av offentlig grön upphandling baserad på kriterierna för Svanen skapar miljönytta och ökad miljömedvetenhet. I detta kan ingå utbildning av inköpsansvariga för t.ex. tvätteri-, rengörings- och tryckeritjänster. De mindre samhällens transparens är en styrka i detta 
sammanhang, eftersom det där inte borde vara lika lätt att ge vilseledande information om sin miljöanpassning som i storstaden.

På Island verkar offentlig grön upphandling med krav på miljöanpassade tjänster ha varit en mycket viktig framgångsfaktor för den snabba utvecklingen av Svanenmärkningen, särskilt när det gäller rengöringsoch tryckeritjänster. Av denna erfarenhet borde man kunna dra lärdomar som kan användas i övriga områden.

På Färöarna pågår det arbete i finansministeriets regi med utveckling av offentliga inköpsregler, men i nuläget finns det inga offentliga riktlinjer för grön offentlig upphandling. Inarbetning av gröna kriterier kan sättas i gång när de grundläggande inköpsreglerna har fastställts.

Den offentliga sektorns upphandling har visat sig vara en viktig del av att marknadsföra "gröna" produkter, inte bara för att upphandlingen sätter press på leverantörer att erbjuda miljömärkta varor och tjänster, utan också för att upphandlingen bidrar till att miljömärkena blir synliga i det lokala samhället. Den offentliga sektorns roll som förebild för övriga organisationer kan också vara en viktig aspekt i detta sammanhang.

\subsection{Gröna nätverk (Svanenklubbar)}

Svanenklubbar eller miljömärkningsnätverk har visat sig vara ett effektivt sätt att främja försäljning av miljömärkta varor och tjänster. De nationella miljömärkningssekretariaten i de fem nordiska länderna har alla etablerat eller håller på att etablera inköparnätverk för privata företag. Sverige har längst erfarenhet av detta, och där har ett sådant nätverk, Svanenklubben, funnits sedan våren 2007 och har i nuläget runt 200 företag och organisationer som medlemmar. ${ }^{44}$ Målet är att miljömärkta varor och tjänster ska prioriteras och bli en självklar del i alla inköpsprocesser. Nätverkets medlemmar får stöd från miljömärkningssekretariatet samt från varandra i att utveckla sina inköpsprocesser i en mer miljöanpassad riktning, samtidigt som de får tillgång till en del utbildning och information. Medlemmarna får också använda klubbens logo i sitt marknadsföringsarbete, men för att vara medlem måste de uppfylla vissa krav och betala en medlemsavgift. I Norge har ett liknande nätverk

${ }^{44}$ Miljömärkning Sverige: Svanens nätverk för inköp med omtanke. http://www.svanen.se/natverket 
funnits sedan $2008^{45}$ och i Danmark och Finland sedan 2012.46 På Island kommer samma typ av nätverk att etablerats under våren 2013.47

Modellen för Svanenklubberna/inköpsnätverken borde kunna kopieras och anpassas för mindre samhällen i Norden, särskilt för de självstyrda områdena. Initiativ till detta kunde eventuellt tas på departementsnivå, eftersom områdena inte har egna miljömärkningssekretariat. Här kunde kommuner eller kommunföreningar också ha en ledande roll, t.ex. i anslutning till deras arbete med Agenda 21. Både Åland och Färöarna har lång erfarenhet av landsomfattande samarbeten med Agenda 21, samordnade av Ålands Agenda 21-kontor resp. Agenda 21 stovan på Färöarna. Här finns det mänskliga resurser som kunde utnyttjas vid etablering och drift av inköpsnätverk, men självklart behövs det också extra finansiering för att komma i gång.

Förslagen i detta avsnitt bör ses i ljuset av att de inte diskuterats med de nämnda aktörerna.

\subsection{Konkurrens med övriga märken}

Det finns en ökande märkeskonkurrens, i vilken Svanen bl.a. konkurrerar med Nyckelhålet, ekologiska märken och övriga märken för livsmedel. Marknadsföringen av dessa har i många fall fått betydligt mer pengar än marknadsföringen av Svanen. Detta gäller dock inte mindre samhällen specifikt.

\subsection{Nya sekretariat?}

Möjligheten, behovet av eller kostnaden för att upprätta egna miljömärkningssekretariat i de självstyrda områdena är en grundläggande fråga när det gäller spridning av Svanen på Färöarna, Åland och Grönland.

Det framkom i intervjuer med Svanenmärkta företag som bidrog till "succéhistorierna" att behovet av egna miljömärkningssekretariat inte

\footnotetext{
45 Miljømerking Norge (2012): Innkjøberklubben.

http://www.svanemerket.no/for-bedrifter/profesjonelle-innkjop

46 Miljømærkning Danmark (2012): Nyt virksomhedsnetværk bidrager til grøn omstilling. Pressemeddelelse

17. oktober 2012. http://www.ecolabel.dk/presse/pressemeddelelser/

PM_lancering_af_nyt_indk\%C3\%B8bernetv\%C3\%A6rk.htm

${ }^{47}$ Anna Sigurveig Ragnarsdóttir, Umhverfisstofnun: Telefonsamtal 16 januari 2013.
} 
upplevs som stort, samt att det kan visa sig vara svårt att bygga upp den kompetens som behövs. Kontaktpersoner i några icke-Svanenmärkta företag har däremot sagt att man skulle kunna ha en friare och snabbare dialog med sekretariatet om det fanns i närregionen, samtidigt som de påpekade att detta kanske inte var ekonomiskt realistiskt.

Generellt är det inte de Svanenmärkta företagen som behöver stöd, utan de som inte har Svanen, är omedvetna eller inte vet hur man kommer igång.

I detta sammanhang bör man också överväga prioritetsordningen, d.v.s. om det vore önskvärt att etablera ett eget sekretariat för att sätta igång processen och väcka intresse hos företagen, eller om man först borde skapa efterfrågan innan man börjar investera i nya sekretariat.

På samma sätt som situationen varierar i de olika självstyrda områdena borde olika lösningar tillämpas.

- På Åland finns det förmodligen inget behov alls, eftersom sekretariaten i Sverige och Finland ligger mycket nära geografiskt. Där rekommenderas snarare en kampanj för att informera företagen om de möjligheter och konkurrensfördelar som Svanen medför. Därmed borde man kunna "aktivera den kraft som finns", för att citera Michael Terry.

- På Färöarna är det förmodligen heller inte dags att etablera ett eget miljömärkningssekretariat, främst av ekonomiska skäl. Däremot kunde man stödja utvecklingen på Färöarna genom att driva en informationskampanj och översätta basinformationen till färöiska, etablera en färöisk webbsida för Svanen, samt även utnämna en kontaktperson hos miljömyndigheterna som har rollen att hjälpa till med kontakter mellan företagen och sekretariatet. Ett annat alternativ vore att anställa en färöiskspråkig medarbetare på miljömärkningssekretariatet i Köpenhamn.

- På Grönland verkar det inte finnas någon efterfrågan alls i detta sammanhang, inte ens på regeringsnivå. Ett första steg kunde vara en informationskampanj riktad till allmänheten, samt eventuellt till företag i turistindustrin, med fokus inte bara på Svanen utan på miljöfrågor mer generellt. 


\section{Rekommendationer}

I detta avsnitt presenteras rekommendationer ang. riktlinjer och åtgärder för att öka antalet Svanenmärkta företag/varor/tjänster i mindre samhällen i Norden, samt en beskrivning av hur detta arbete kan organiseras och finansieras. Det bör framhävas att rekommendationerna är författarens och återspeglar inte nödvändigtvis Småsamfundsgruppens synpunkter. Trots detta skulle de kunna vara ett viktigt underlag för gruppens framtida arbete med att stärka Svanens ställning i mindre samhällen i Norden.

\section{Inga nya miljömärkningssekretariat}

Det verkar inte finnas behov av etablering av nya miljömärkningssekretariat i de självstyrda områdena. Färöarna är ett undantag. Där finns det sannolikt ett visst behov, men etablering av ett sekretariat verkar vara tveksamt ur ekonomisk och professionell synpunkt. Etablering av nya sekretariat rekommenderas därför inte.

\section{Informationskampanjer om miljö och miljömärkning}

Det rekommenderas att nationella miljömyndigheter tar initiativ till informationskampanjer om miljö och miljömärkning i de självstyrda områdena i samarbete med miljömärkningssekretariateten i Danmark, Sverige, Finland, Norge eller Island. En nordisk "roadshow" rekommenderas som ett första steg i detta, t.ex. i form av en temadag i varje område, där man informerar om Svanen och miljömärkning i allmänhet och samtidigt söker skapa en översikt över det aktuella intresset i det berörda området/landet. Nordiska medel borde kunna användas för förberedelser och samordning av detta samt för ersättning för resekostnader, medan det lokala genomförandet kan finansieras med nationella medel. Om intresse finns kunde ett nästa steg vara mer sektorspecifikt och/eller riktat mot specifika kundgrupper, t.ex. småbarnsföräldrar.

Behovet av informationskampanjer varierar mellan olika länder/områden. På Åland borde fokus sättas på företag som primär målgrupp. På Färöarna borde fokus sättas på företag samt på allmänheten. På Grönland borde allmänheten vara den primära målgruppen. 


\section{Främja grön offentlig upphandling}

Grön offentlig upphandling borde främjas i de självstyrda områdena. Utbildning av inköpsansvariga för t.ex. tvätteri-, rengörings- och tryckeritjänster rekommenderas som ett första steg i detta. På Grönland skulle ett första steg kunna vara en undersökning av befintliga Svanen-märkta produkter på marknaden. På Färöarna kan inarbetning av gröna kriterier sättas i gång när de grundläggande inköpsreglerna har fast-ställts.

\section{Etablera inköparnätverk (Svanen-/miljömärkningsklubbar)}

Inköparnätverk borde etableras i de självstyrda områdena, baserat på modeller som redan finns i samtliga fem nordiska länder. Det rekommenderas att nationella miljömyndigheter tar initiativ till detta i samarbete med miljömärkningssekretariaten i berörda länder samt med kommunala nätverk inom Lokal Agenda 21.

\section{5. Översättning av material}

Det rekommenderas att material om Svanenmärkningen översätts till grönländska och samiska samt till färöiska efter behov. Nationella miljömyndigheter borde ta initiativ till detta i samarbete med miljömärkningssekretariateten. I Grönlands fall borde fokus generellt sättas på underlag för miljöutbildning i första hand.

\section{Träning/utbildning av Svanenkonsulter}

Det rekommenderas att nationella miljömyndigheter på Färöarna och Åland tar initiativ till utbildning av Svanenkonsulter i samarbete med miljömärkningssekretariaten i berörda länder, samt att ansökningsavgiften halveras för producenter som anlitar godkända Svanenkonsulter i enlighet med den norska modellen.

\section{Kontaktperson på Färöarna}

Det rekommenderas att miljömyndigheterna på Färöarna utnämner en av sina medarbetare till kontaktperson med rollen att hjälpa till med kontakter mellan färöiska företag och miljömärkningssekretariatet i Köpenhamn eller ev. Reykjavik. Alternativt rekommenderas att sekretariatet anställer en färöiskspråkig medarbetare som får i uppdrag att sköta kontakterna med företag på Färöarna.

\section{Undersökningar}

Det rekommenderas att en undersökning görs av kunskapen om Svanen och miljömärkning i övrigt på Färöarna, Grönland och Åland, samt hos den samiska befolkningen i Nordnorge. Nationella miljömyndigheter bör 
ta initiativ till detta. En undersökning av andelen Svanenmärkta produkter i respektive länder/områden borde också göras i anslutning till detta.

\section{Avgiftsstruktur}

Inga ändringar föreslås av Svanens avgiftsstruktur.

Tabell 2 innehåller en sammanfattning av rekommendationerna ovan i ett mer schematiskt format.

\begin{tabular}{|c|c|c|c|c|c|c|}
\hline \multicolumn{7}{|c|}{ Rekommendation } \\
\hline Nr. & Text & Island & N-Norge & Färöarna & Åland & Grönland \\
\hline 1 & Nya sekretariat & - & - & Nej & Nej & Nej \\
\hline 2 & $\begin{array}{l}\text { Informations- } \\
\text { kampanjer/ } \\
\text { temadagar }\end{array}$ & - & - & $\begin{array}{l}\text { Målgrupp: } \\
\text { Företag + } \\
\text { allmänheten }\end{array}$ & $\begin{array}{l}\text { Målgrupp: } \\
\text { Företag }\end{array}$ & $\begin{array}{l}\text { Målgrupp: } \\
\text { Allmänheten }\end{array}$ \\
\hline 3 & $\begin{array}{l}\text { Grön offentlig } \\
\text { upphandling }\end{array}$ & På gång & På gång & $\begin{array}{l}\text { Utbildning } \\
\text { ett första } \\
\text { steg }\end{array}$ & På gång & $\begin{array}{l}\text { Undersökning } \\
\text { av befintliga } \\
\text { produkter }\end{array}$ \\
\hline 4 & Inköparnätverk & På gång & På gång & $\begin{array}{l}\text { Nationella } \\
\text { miljömyn- } \\
\text { dighets- } \\
\text { initiativ }\end{array}$ & $\begin{array}{l}\text { Nationella } \\
\text { miljömyn- } \\
\text { dighets- } \\
\text { initiativ }\end{array}$ & $\begin{array}{l}\text { Nationella } \\
\text { miljömyn- } \\
\text { dighets- } \\
\text { initiativ }\end{array}$ \\
\hline 5 & $\begin{array}{l}\text { Översättning av } \\
\text { material }\end{array}$ & - & $\begin{array}{l}\text { Till } \\
\text { samiska }\end{array}$ & $\begin{array}{l}\text { Till } \\
\text { Färöiska } \\
\text { (efter behov) }\end{array}$ & - & $\begin{array}{l}\text { Till } \\
\text { Grönländska - } \\
\text { Fokus på } \\
\text { generell } \\
\text { information }\end{array}$ \\
\hline 6 & $\begin{array}{l}\text { Utbildning av } \\
\text { Svanenkonsulter }\end{array}$ & - & - & $\begin{array}{l}\text { Nationella } \\
\text { miljömyn- } \\
\text { dighets- } \\
\text { initiativ }\end{array}$ & $\begin{array}{l}\text { Nationella } \\
\text { miljömyn- } \\
\text { dighets- } \\
\text { initiativ }\end{array}$ & - \\
\hline 7 & $\begin{array}{l}\text { Kontaktperson på } \\
\text { Färöarna }\end{array}$ & - & - & $\begin{array}{l}\text { Nationella } \\
\text { miljömyn- } \\
\text { dighets- } \\
\text { initiativ }\end{array}$ & - & - \\
\hline 8 & Undersökningar & - & $\begin{array}{l}\text { Inom } \\
\text { samisk } \\
\text { befolkning }\end{array}$ & $\begin{array}{l}\text { Nationella } \\
\text { miljömyn- } \\
\text { dighets- } \\
\text { initiativ }\end{array}$ & $\begin{array}{l}\text { Nationella } \\
\text { miljömyn- } \\
\text { dighets- } \\
\text { initiativ }\end{array}$ & $\begin{array}{l}\text { Nationella } \\
\text { miljömyn- } \\
\text { dighets- } \\
\text { initiativ }\end{array}$ \\
\hline 9 & Ny avgiftsstruktur & Nej & Nej & Nej & Nej & Nej \\
\hline
\end{tabular}





\section{Referenser}

\section{Litteratur och webbsidor}

Ecolabel Finland (2012): Creating the future now.

http://www.ecolabel.fi/ymparistomerkki/in_english.

Estra/Vasti (2012): Estra/Vasti svanamerkt prentsmiðja. Nyhet på hemsida 23 oktober 2012.

http://estra.fo/tiacuteethindi/57-estravasti-svanamerkt-prentsmiethja/\#57

Folktinget - Svenska Finlands folkting (u.d): Svenskan i Finland.

http://www.folktinget.fi/sve/svenskan

ISO (International Organization for Standardization), (1999): International Standard ISO 14024. Environmental labels and declarations - Type I environmental labelling

- Principles and procedures. ISO 14024:1999(E). ISO, Schweiz.

Miljømerking Norge (2012): Hva kostar det?

http://www.svanemerket.no/for-bedrifter/sok-om-svanemerket/avgifter

Miljømerking Norge (2012): Innkjøberklubben.

http://www.svanemerket.no/for-bedrifter/profesjonelle-innkjop

Miljømærkning Danmark (2012): Hvad koster det at få et miljømærke?

http://www.ecolabel.dk/producenter/Hvad+koster+det+at+faa+et+miljoemaerke

Miljømærkning Danmark (2012): Nyt virksomhedsnetværk bidrager til grøn omstilling. Pressemeddelelse 17 oktober 2012.

http://www.ecolabel.dk/presse/pressemeddelelser/

PM_lancering_af_nyt_indk\%C3\%B8bernetv\%C3\%A6rk.htm

Miljömärkning Sverige AB (2012): Svanens nätverk för inköp med omtanke.

http://www.svanen.se/natverket

Miljömärkning Sverige AB (2012): Vad kostar det?

http://svanen.se/Foretag/avgifter

Miljömärkning Sverige AB (2013): Kriterier.

http://www.svanen.se/Foretag/Kriterier

Nordiska ministerrådet (2012): Svanen och EU Ecolabel. Succéhistorier i nordiska småsamfund. Nordiska ministerrådet, Köpenhamn.

http://www.norden.org/sv/publikationer/publikationer/2012-553

Retsinformation.dk (2010): Bekendtgørelse af lov om miljøbeskyttelse. LBK nr 879 af 26.06.2010. Miljøbeskyttelsesloven. Offentliggørelsesdato: 09.07.2010. Miljöministeriet, Danmark.

https://www.retsinformation.dk/Forms/r0710.aspx?id=132218

Retsinformation.dk (2010): Bekendtgørelse om det europæiske og det nordiske miljømærke. BEK nr 447 af 23.04.2010. Offentliggørelsesdato: 30.04.2010. Miljöministeriet, Danmark.

https://www.retsinformation.dk/Forms/R0710.aspx?id=131387\&exp=1

Sermitsiaq (2012): Naqitat kaster håndklædet i ringen. Nyhet 30 april 2012.

http://sermitsiaq.ag/node/124937

Store norske leksikon (u.d): Språk i Norge. http://snl.no/Norge/spr\%C3\%A5k 
Umhverfisstofnun (2013): Ágætis byrjun.

http://www.ust.is/einstaklingar/umhverfismerki/svanurinn/agaetis-byrjun Umhverfisstofnun (2012): Kostnaður.

http://www.ust.is/atvinnulif/svanurinn/kostnadur

Umhverfisstofnun (2013): Sjálfbært samfélag. Svansleyfi.

http://www.ust.is/einstaklingar/astand-umhverfisins/sjalfbaert-samfelag

Vistvæn innkaup (Grön upphandling) (2013). Hemsida. http://www.vinn.is

\section{Intervju, e-post eller telefon}

Alvhild Hedstein, Miljømerking Norge: E-post 14 nov 2012.

Anna Sigurveig Ragnarsdóttir, Umhverfisstofnun: Telefonsamtal 16 jan 2013. Anni á Hædd, Inrikesministeriet Tórshavn: Telefonsamtal 15 april 2013.

Björn-Erik Lönn, Nordisk koordinator för Svanen: E-postar och telefonsamtal 16 jan 2013.

Elva Rakel Jónsdóttir, Umhverfisstofnun: Telefonsamtal 14 nov 2012 och 15 april 2013.

Gunnar Á. Gunnarsson, Tún: Telefonsamtal 4 jan 2013.

Jóhanna Zachariasen, Kemilux: E-post 30 nov 2012.

Kirsi Auranmaa, Miljömärkning Finland: E-post 21 nov 2012.

Klaus Pärnänen, Mariehamns Tryckeri: E-post 23 nov 2012.

Maria Gunnleivsdóttir Hansen, Umhvørvisstovan: E-post 5 feb 2013.

Marianne Holdgaard Rasmussen, Hotel Hans Egede: E-post 8 jan 2013.

Michael Björklund, Smakbyn: E-post 5 jan 2013.

Michael Terry, TidningsTryckarna: Telefonsamtal 27 nov 2012.

Mona Kårebring-Olsson, Ålands landskapsregering: E-post 15 april 2013.

Ragnar Unge, Miljömärkning Sverige: E-post 25 okt 2012.

Tine Due Hansen och Lisbeth Engel Hansen, Miljømærkning Danmark: E-post 9 jan 2013

Uiloq Mulvad Jessen, Grönlands Självstyre: E-post 12 nov 2012. 


\section{Summary}

The Nordic Swan is considered to be one of the best examples of successful ecolabelling in the whole world. The Swan label has had a very strong image in Norway, Sweden, Finland and Denmark for a long time. Iceland has also seen a rapid development in the last four years, reflected in a fivefold increase of the number of Swan licences over this period. On the other hand, the Swan has not enjoyed the same success in smaller Nordic communities. No Swan licence has so far been issued in Greenland, and there are only two ecolabelled companies in the Faroe Islands and four in Åland.

In the autumn of 2012 the Nordic Council of Ministers published a booklet with 18 good examples ('success stories') of small companies operating in small Nordic communities which have had their products or services awarded the Swan or EU Ecolabel. These examples show that ecolabelling is not only possible but also profitable, not just in the big cities but also in smaller communities. The present project is based on these 'success stories' and involves a more detailed study of tools that could be used to make the Swan label more accessible/relevant for producers of goods and services in small Nordic communities.

There are currently criteria for Swan labelling of 61 different product groups. Only a small number of these are relevant to the smaller Nordic communities, because apart from fishing there is relatively little manufacturing industry in the areas concerned. On the other hand, there are a lot of different service companies, not least in the tourist sector, where ecolabelling ought to be extremely relevant, particularly given how dependent the tourist industry is on unspoilt nature.

Based on a rough estimate of the number of companies in the relevant product groups and the percentage of companies awarded the Swan label for their products or services, only 31 companies out of some 1,700 in Iceland, the Faroe Islands, Åland and Greenland have had their products or services ecolabelled. So there would seem to be great potential for Swan ecolabelling in these areas, particularly within service sectors such as hotels, restaurants and grocery stores. Printers, cleaning contractors and laundries are also quite promising.

Two main factors have been cited to explain the success of the Swan label in Iceland in the last four years: a deliberate political strategy and 
an effective policy for green public procurement. It should be possible to draw lessons from this experience that could be applied in other areas. However, it should also be noted in this context that, as an independent member country of the Nordic Council of Ministers, Iceland differs from the Faroes, Greenland and Åland when it comes to ecolabelling. In Iceland, the Nordic Swan has a formal legal status as an official ecolabel with its own national ecolabelling secretariat. Companies in the Faroes, Greenland and Åland, on the other hand, have to rely on support from the national secretariats in the five member countries of the Nordic Council of Ministers.

According to information from national environmental authorities in the Faroes, Greenland and Åland and from the national ecolabelling secretariats, there has been no noticeable demand for ecolabelling from companies in the autonomous regions. However, no firm conclusions can be drawn from this until the matter has been examined more in detail. There may be little demand because companies do not find the support of the ecolabelling secretariats accessible due to geographical distance or language barriers, or because there is no official contact person in government to deal with this demand.

Based on the information given in this report, it is not recommended that new ecolabelling secretariats be established in the autonomous areas. On the other hand, national authorities should take the initiative in information campaigns on the environment and ecolabelling in the autonomous areas, in collaboration with and drawing on expert support from the ecolabelling secretariats in Denmark, Sweden, Finland, Norway or Iceland. A Nordic 'roadshow' is recommended as a first step in this process, possibly in the form of a 'theme day' in each area to talk about the Swan label and ecolabelling in general and try to gain an overview of the current level of interest in the area/country concerned. Nordic funds should ideally be used to prepare and coordinate these sessions and to cover travel costs, while the local implementation can be financed from national funding. If there is sufficient interest, the next step could be more sector-specific and/or directed at specific customer groups such as parents of small children.

The need for information campaigns varies between different countries/areas. In Åland, the focus should be on companies as the primary target group. In the Faroes, the focus should be on companies and the general public. In Greenland, the public should be the main target group.

Promoting green public procurement is another measure recommended to support the development of the Swan label in smaller Nordic communities. Training for purchasing managers in laundry, cleaning and 
printing businesses is recommended as a first step in this process, and green criteria can be incorporated into national procurement policies when the underlying purchasing rules are defined.

Among other recommendations in the report are the establishment of 'Swan clubs', translation of materials, training of Swan consultants, surveys of awareness of the Swan label and existing ecolabelled products, and for the environmental authorities in the Faroes to appoint one of their staff as a contact person tasked with assisting in dealings between Faroese companies and the ecolabelling secretariat in Copenhagen or possibly Reykjavik. 
Nordiska ministerrådet

Ved Stranden 18

DK-1061 København K

www.norden.org

Svanen i mindre samhällen

- hur kan man stödja utvecklingen?

Hösten 2012 publicerade Nordiska ministerrådet ett häfte med 18 goda exempel ("succéhistorier") på miljömärkning av varor eller tjänster från små företag i mindre samhällen i Norden. Dessa exempel visar att miljömärkning inte bara är möjlig utan också lönsam, inte bara i storstäderna utan också i mindre samhällen.

Denna rapport bygger vidare på "succéhistorierna" och innebär en närmare och mer detaljerad undersökning av vilka styrmedel som skulle kunna användas för att göra Svanen mer tillgänglig/aktuell för producenter av varor och tjänster i mindre samhällen i Norden. Undersökningen har gjorts av Environice på Island på uppdrag av Nordiska ministerrådets Småsamfundsgrupp, en undergrupp till arbetsgruppen för hållbar konsumtion och produktion. 